\title{
FUNDING THE NON-PROFIT WELFARE SECTOR: EXPLAINING CHANGING FUNDING SOURCES 1960-1999
}

\author{
by
}

\section{GABRIELLE BERMAN, ${ }^{*}$ ROBERT BROOKS ${ }^{* *}$ and JOHN MURPHY}

\begin{abstract}
The non-profit welfare sector in Australia is dominated by several large organisations which are predominantly older, faith-based, welfare agencies. The success of these agencies is in part due to their ability to diversify funding sources in response to current economic and political environments. This paper analyses the changing funding mix of two of these organisations. The analysis finds some variability in the composition of funding sources over time. However, we also find that to some extent the agencies smooth out variations from one source with other sources of funding. The agencies do not appear to be able to raise funds in a counter-cyclical manner.
\end{abstract}

Keywords: Non-profits, Fundraising, Welfare agencies, Contract state, Salvation Army, Brotherhood of St Laurence

\section{JEL Classification: L31}

\section{Introduction}

The non-profit welfare sector in Australia is dominated by several large organisations which are predominantly older, faith-based, welfare agencies (Industry Commission, 1995). Their success, prominence, and longevity can be attributed to several factors, including reputation and public profile, the support provided by religious affiliation, independent funding sources such as property and investments built up over time, and their ability to diversify and stabilise their funding sources in response to economic

* Planning Group, RMIT University.

** Department of Econometrics and Business Statistics, Monash University.

*** The Australian Centre, Faculty of Arts, University of Melbourne.

The research in this project was funded by an RMIT VRII small grant to the authors, and an ARC Discovery grant (DP0343854) to John Murphy. The authors also wish to thank two referees and the journal editor for their helpful comments on an earlier version of this paper. 
fluctuations. This paper focuses on their ability to diversify and stabilise their funding sources, by examining the mix of funding available over time to two large agencies.

The two faith-based welfare organisations studied are the Brotherhood of St Laurence (BSL) and the Salvation Army (SA). These have been chosen because relatively long and consistent spans of funding data are available. The paper uses an econometric model to analyse the impact on these organisations of changes in basic economic conditions over the period 1960-1999. The paper examines the links between the levels of funding raised from a variety of sources. The plan of the paper is as follows. In Section 2, we analyse the research literature on the relations between the non-profit welfare sector and governments in the mixed economy of welfare, detailing previous economic analyses of the non-profit sector. Section 3 presents a brief history of the two case study agencies-the Brotherhood of St Laurence and the Salvation Army -in the context of changing Federal and State government policies. Section 4 describes the data, and also presents the results of the empirical analysis. Finally, Section 5 draws some conclusions from the analysis.

\section{The Non-profit Welfare Sector in the Mixed Economy of Welfare}

Examining shifts in the funding sources of non-profit welfare agencies is one means of assessing relations within the mixed economy of welfare. It can help illuminate how the relations between government and non-government sectors have altered over time. Government funding-in the form of grants or government contracts to provide services-is one measure of these relationships, indicating the responsibilities taken on by welfare agencies and the funding support provided by governments. By contrast, the ability of non-government agencies to raise their own funds-through commercial and investment income, bequests, and fundraising-is also a measure of their independence and autonomous action.

The research literature about the political, contractual and funding relationships between governments and non-profit welfare organisations in Australia (McDonald, 1997; Alessandrini, 2002) and elsewhere (Gronbjerg and Smith, 1999; Gronbjerg and Salamon, 2003) focuses on the impact on the organisations themselves of market style regimes and government contracting of welfare services. This type of research is largely expository and/or qualitative and mostly ignores the associated issue of whether these organisations are able to draw on alternative non-government funding sources.

There is some research that uses case studies to consider the implications of funding sources for non-profit organisations. Gronbjerg (1991) examines six medium-sized welfare organisations with different funding profiles to highlight the implications of various funding relationships. The focus in Gronbjerg's (1991) research, however, is on the mission of the organisation. There is little attention given to examining changes in funding sources over time, nor indeed any investigation of changes in sources of funding over time.

Funding, and all that goes with it, has been a focus in some of the research literature. Lewis (1993) examined funding and dependency in four case studies as one way of assessing the implications of the contract state for British welfare agencies, while Rochester (1996) has studied the ways the same sector has dealt with changes to funding criteria. Tennant (2001) provides a useful historical overview of the shifting relations between these sectors in the mixed economy. Much of the literature has been 
about how non-profit organisations respond to the relatively new regime of more contractual relationships with governments, and what implications this has for how they run themselves. Within the context of this literature, an empirical analysis of the sources of funds available to the BSL and the SA can provide insight into how the two agencies have positioned themselves over the period.

Theories of the nature of the non-profit welfare sector, and of its relationship with government, have posited several contending and overlapping arguments that provide an important backdrop to this analysis. Why do non-profit welfare agencies exist and how do they fit into a mixed economy of welfare? A number of researchers have suggested answers to these questions. Rose-Ackerman (1996) proposed that lack of equity ownership offers a solution for those services that are difficult to evaluate and where the recipient of services is not necessarily the financier. Weisbrod (1977) argued that market and state failure provide the impetus for the establishment of non-profit organisations. Weisbrod explains that the market is unwilling to provide public goods that generate little profit and that are available to all, regardless of whether or not they pay. Yet where considerable differences of opinion exist about which public goods are valued, governments tend only to reflect the interests of median voters. "In such circumstances", as Salamon and Anheier have put it, "people will turn to non-profit organizations to supply the public goods they cannot secure through either the market or the state" (Salamon and Anheier, 1998, p. 220). Young characterises this as the view that non-profit agencies supplement government failure, meeting needs that the state is too unwieldy to attend to (Young, 2000).

A second argument focuses more on the supply of public goods, drawing attention to the importance of key figures ('social entrepreneurs') and the institutional imperatives of the Churches. On this reading, Church welfare agencies, competing with each other for public profile and for adherents, need to maintain their presence in the mixed economy of welfare. A third argument is that non-profit agencies have a niche in areas where neither prices nor knowledge provide enough information for 'consumers'. Because they are not motivated by profit and are assumed to be more altruistic, nonprofit agencies are more trusted. Purchasers who cannot realistically evaluate the quality of a nursing home for their aged parent may be more inclined to turn to those who are not manifestly motivated by profit (Salamon and Anheier, 1998). Billis and Glennerster define this motivation as a "'non-distribution constraint": those who control the organisation have less incentive to take advantage of their customers. Voluntary organisations therefore have a comparative survival advantage" (Billis and Glennerster, 1998, p. 83).

To a large extent, these theories draw on classical economic theory and its presumption of the utility-maximising individual to explain the nature of the mixed economy of welfare. But others have argued that the particular mix in any given society has complex 'social origins', based on the patterns of historical development, on balances of power and politics, on the historic role of the Churches within a society, and on the nature of its politics. In developing this argument about the social origins of civil society, Salamon and Anheier (1998) have drawn on models of welfare regimes in order to propose that there is an inverse relationship between levels of social spending and the size of the non-profit sector in liberal and social democratic regimes, and that in both liberal and social democratic regimes the non-profit sector is likely to be more significantly financed from private charitable funds than from taxation. 


\section{GABRIELLE BERMAN, ROBERT BROOKS \& JOHN MURPHY}

Based on this argument, the non-profit and government sectors are seen as complementary to each other, engaged in a partnership in which governments often fund what the non-profit sector delivers. Helmut Salamon (1995) has been one prominent advocate of this view of complementarity. Young (2000) notes that the argument draws on a combination of public-choice and transaction-cost theories. Governments choose to contract non-profit welfare agencies to deliver services because it can be a cheaper option, because the local knowledge of welfare agencies frees governments from the need to develop complex knowledge of the heterogeneous preferences of citizens, or because welfare agencies can take on the task of sorting out 'free riders' by using their local knowledge to customise services.

Alongside these arguments about welfare agencies as a supplement for government failure or as a complementary partner with government, Young notes a third category of relationship, in which welfare agencies and governments are adversaries. Governments often attempt to control and monitor welfare agencies, particularly through contractual constraints as the 'strings' attached to their funding. In turn, some agencies take on an advocacy role of agitating for social programs and criticise governments for policy inaction. Young (2000) argues that this perspective also draws on Weisbrod's argument about policy failure. If governments are unable to discern minority preferences and have little initiative, it is left to welfare agencies to pioneer demonstration projects or champion unpopular policy ideas.

To some extent, this third view of an adversarial relationship also draws on ideas about legitimacy. Moore (2001) has noted that legitimacy needs to be considered in explaining the shifting boundary between government and non-profit provision. Governments need to demonstrate their democratic legitimacy; by showing they are concerned with social welfare. In turn, welfare agencies need to maintain their credibility as champions of the poor, and are hence wary of being too dependent on government funds, lest they are unable to bite the hand that feeds them. If this leads them insist on their autonomous role as critics, their increasingly intermeshed role with government contractualism can compromise, or at least challenge, this autonomy. Maintaining legitimacy and public credibility in turn links back to the issues of trust previously noted.

Finally, Billis and Glennerster have proposed that the non-profit welfare sector has distinctive comparative advantages. Drawing on a mix of public-choice theory and close knowledge of how welfare agencies work, they propose that non-profit agencies have more 'ambiguous' and hence flexible structures (for example, they have the features of both bureaucracies and of associational groups). They suggest that this characteristic 'blurring' is an advantage in dealing with clients with complex needs, because "the gap between users and those in authority can be less, given the potential for greater motivation, sensitivity to, and knowledge about client need" (Billis and Glennerster, 1998, p. 91). But if this is so, they conclude, then when "increased size leads to increased differentiation and separation of stakeholder roles, . . . comparative advantage begins to diminish ... [and] may be destroying the very comparative advantages the sector has to offer" (Billis and Glennerster, 1998; pp. 96-97).

Considine's analysis of the non-profit agencies involved in the 'quasi market' of Job Network in Australia up to 1999 suggests something similar. Job Network is the Commonwealth Government's privatised employment and job-search service, for which both the non-profit and for-profit sectors have tendered to be providers under 
contract. With significant Government control over contract terms, increased competition with private contractors, and the need to develop services that maximise financial sustainability, non-profit organisations tended to converge towards similar behaviour, to some extent losing the values of service, social justice, and community that make them distinctive (Considine, 2003). It is worth noting that both of the agencies considered in this paper have been involved in Job Network, though this issue lies outside our research focus. In the context of the literature on the relationships between government and non-profit welfare agencies, the paper now examines shifts in the funding sources of the two agencies, providing thereby some insight into their relationships in the mixed economy of welfare, and some clues as to how they draw on other funding sources to maintain their independence and autonomy.

\section{The Brotherhood of St Laurence and the Salvation Army}

The Brotherhood of St Laurence (BSL) had its origins in the 1930s Depression, when the Anglican priest, Father Albert Tucker, formed a new religious fraternity-the Brotherhood-to provide emergency housing for unemployed men. From 1933, the BSL has been based in the working-class suburb of Fitzroy in Melbourne. By 1945, it was a coherent and well-established welfare agency concentrating on poverty relief, advocacy of slum clearance and the provision of accommodation for the elderly poor. It was never really a religious fraternity. Indeed, in recognition of Tucker's absolute dominance of the organisation, it was sometimes known as the 'Tuckerhood of St Laurence'. The leaders who followed Tucker were less idiosyncratic, and built the agency into a major player in the welfare field, based on its commitment to social justice and policy development. What particularly characterised the BSL in the years under review were its community development work (increasingly based on radical social work), its policy advocacy (increasingly based on quality research), and its provision of aged persons' accommodation (increasingly funded by the state) (BSL, 2001; Carter, 1967; Handfield, 1980).

The Salvation Army is a very different organisation. Founded in Britain in 1865 as a breakaway from Methodism, it had a mission to bring both immediate poverty relief and Christian salvation to the poor. By 1880, the first 'Salvationists' had established themselves in Adelaide and two years later in Melbourne (Bolton, 1980; Tarling, 1980; Salvation Army, 2001). Over the following years, the Army was characterised by its fervent evangelism, by a distinctive quasi-military organisation, and by a significant presence in welfare work. By contrast with the BSL, the work of the SA has been little researched. However, the SA has established a major position in the welfare field, particularly through its enormous capacity to raise funds through an annual Red Shield Appeal, an activity that became much more prominent and successful from the $1980 \mathrm{~s}$ onwards. Under the period covered by this paper, the real value of donations (in 1990 dollars) rose from some $\$ 400,000$ to over $\$ 17$ million (Salvation Army, various dates).

Several major trends can be identified over the period under review, which reflect both the welfare activities of the BSL and the SA and their relationships with governments. First, both have made substantial investments of energy and resources in providing aged accommodation in the post-war years. With the introduction by the Menzies Commonwealth Government of the Aged Persons Homes Act (1954), a pattern was set by which Commonwealth governments encouraged (through matching funds for 
capital expenditure) Church-based agencies to build and operate accommodation for the aged (Kewley, 1973). In addition, the Victorian State Government encouraged the same trend by providing subsidies to the operating costs of aged accommodation, though these subsidies fell away from the mid-1960s. As result, the number of aged-care institutions in Victoria grew dramatically from about twenty in 1945 to about two hundred by 1975 (Victoria, HCC, various dates). Another significant area of government-funded service provision was in the growth from the late 1970s of programs dealing with growing unemployment, including labour market programs funded by the Commonwealth Government.

Second, over the period under review the BSL has had a significant role in antipoverty campaigns-particularly in its local area. During the 1950s, it was very active in advocating slum clearance, and later in raising awareness of, and developing programs to tackle, the poverty of the elderly, of low-income families, and the unemployed. During the 1970s, it pioneered community development programs with low-income families, and during the 1980s it had a substantial focus on unemployment and poverty. This often involved project funding from governments. But rather than building up large programs and services (with the exception of housing the elderly), the BSL has seen its role as pioneering and trialling innovative ideas and then getting others-particularly the Victorian State Government- to take them up (Handfield, 1980).

Third, neither the BSL nor the SA has been involved in another major area of the Victoria non-government welfare-sector accommodation, such as orphanages and the provision of children's services. However, the SA has had a substantial role in emergency accommodation and crisis services, such as providing shelter for the homeless, alcohol and drug treatment programs, and assistance to the survivors of domestic violence. These are funded both through the organisation's own funds, but also from Commonwealth and particularly state government grants (Salvation Army, 2001). The SA has had less emphasis than the BSL on community development and anti-poverty strategies, preferring to focus on immediate and emergency relief.

Finally, since the 1970s, the BSL has developed a substantial research and policy advocacy capacity, through investing in research reports raising issues of poverty and unemployment. During the 1980s and into the 1990s, the BSL was a significant player nationally in tax and welfare debates, its interventions being highly regarded because they were based on solid research and local knowledge. To an extent, the BSL became the 'voice' of the non-government welfare sector during this period, and a credible critic of government policies. Over the period examined, the SA had little or none of this research and policy role, though its prominent profile gave it a platform for public commentary. It is noteworthy in the context of examining the sources of its funds that the BSL always attempted to fund its research and advocacy from its own resources or from specific donations, explicitly in order to maintain the independence of this policy work and to avoid problems of having to 'bite the hand that fed it' (Wilson, 2003).

This relatively complex set of functions and funding arrangements with governments is consistent with the range of relationships sketched by Young (2000). Examining the funding sources of these two key non-profit agencies over time can help to illuminate these relationships and the dilemmas they can involve. To what extent are the BSL and SA supplementing government and market failure? This aspect of the relationship would lead to the hypothesis that in times of prosperity, and if governments 
are relative passive, then supplementation might be demonstrated in low government funding, but increases in other sources of funding. A more complementary role of the non-profit welfare sector would lead to the expectation that we can track increasing government grants to fund services provided by the agencies, such as accommodation for the aged and labour-market programs. Finally, the more adversarial aspects of the relationship between government and the non-profit welfare sectors would depend on the extent to which agencies are able to maintain independent sources of income, such as from fundraising, bequests and commercial income, in order to preserve their autonomy and capacity to take an independent and sometimes adversarial stance.

\section{Results}

The data for this paper have been derived from the annual reports of the BSL and the Salvation Army over the period from 1960 to 1999. The data for the BSL are divided into five broad funding sources: (1) government grants; (2) fundraising; (3) commercial ventures; (4) accommodation charges and service fees; and (5) net investment revenues. The data for the SA is divided into three broad funding sources: (1) government grants; (2) fundraising; and (3) commercial ventures. Unfortunately, we are unable to include data on accommodation charges and service fees or net investment revenue in the analysis owing to an inability to obtain such data. The differences in these aggregated categories are the result of the reporting formats of the available data, with aggregation aimed at producing as consistent as possible a time-series over this period. Unfortunately, further disaggregation is not possible, given changes in reporting formats over time.

Government grants include service delivery subsidies for areas such as aged care, homeless accommodation, sheltered workshops for people with disabilities, as well as discretionary grants for specific welfare projects, including labour-market projects. For both the BSL and the SA, government grants originated from both Commonwealth and State government sources. Fundraising includes auxiliaries, donations, and legacies. In the case of the SA, it includes the annual Red Shield Appeal. Commercial ventures comprise revenues from opportunity shops, donated goods, and paper recycling operations variously owned and run by the BSL and the SA. In the case of the BSL, accommodation charges and service fees include client fees from nursing homes, agedcare hospitals, family day-care services, child-care services as well as revenue from research publications. Finally, net investment revenue rather than gross investment revenue is used in our analysis, due to the absence of more detailed accounts. All data has been converted into real figures to account for inflation, benchmarked to 1990 values.

Finally, two caveats need to be noted for the data. Since the late 1990s, both organisations have been involved in contracts with the Commonwealth Government to provide Job Network management of the unemployed, but information on these substantial and often controversial contracts has not been available to us. Both the BSL and the SA established separate legal entities to receive and manage these contracts (respectively called Job Futures and Employment Plus), and so this takes these government funds out of the reports consulted. In addition, commercial-in-confidence constraints and government contractual obligations on the agencies that prevent their 


\section{GABRIELLE BERMAN, ROBERT BROOKS \& JOHN MURPHY}

making public commentary on the Job Network scheme have meant that information about these contracts is unavailable.

First, the data for the BSL is particularly consistent in its reporting format, being based on annual reports to Parliament of a single agency, based in Melbourne but with some services in regional centres in Victoria. By contrast, the SA data is much less complete and inconsistent in its reporting formats. Other differences are due to the SA's organisational structure. The entity involved is the Salvation Army Southern Territory rather than Victoria only (the Southern Territory encompasses Victoria, Tasmania, South Australia, Western Australia, and the Northern Territory, while the Eastern Territory encompasses New South Wales, the ACT, and Queensland.) This means there can be little state-level comparability between the two agencies, for example as a result of specifically Victorian policy changes.

Second, the data used for the Salvation Army have to do with its 'Social Trust'. This trust was selected because it is used to organise and fund community services. The other two major trust funds (Property Trust and General Trust) are used to accumulate and manage resources (such as the SA's substantial property portfolio), and funds are transferred between the trusts to cover specific services and functions. This means that only part of the SA's funding structure is being considered in this paper, but it is the part most focused on welfare work, and hence most comparable with the BSL.

FIGURE 1

BROTHERHOOD OF ST LAURENCE, 1960-1999, SOURCES OF REAL INCOME IN $\$ 1999$

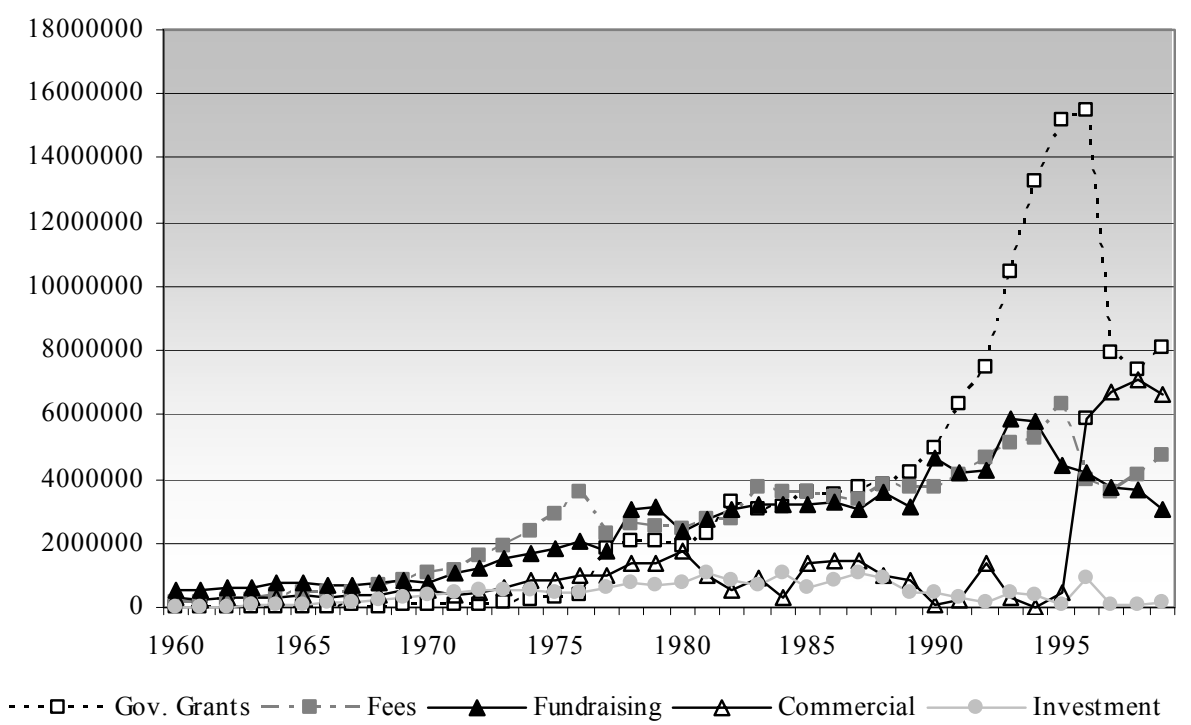

Source: Annual Reports, Brotherhood of St Laurence.

The data for BSL are broadly consistent except in 1996-1997 where there was a marked reduction in total income, largely due to a substantial decrease in government discretionary grants after 1997. The key explanation for this decline is that the Howard 
Commonwealth Government substantially de-funded labour market programs in which the Brotherhood had been involved for well over a decade. As explained above, the Commonwealth unemployment services shifted to tendering out the management of the unemployed to Job Network agencies. The decline in government funding is also marginally offset by increases in the real net income from commercial ventures, reflecting a restructuring and rationalisation of the Brotherhood's recycling and opportunity shop enterprises in the mid-1990s.

\section{FIGURE 2}

SALVATION ARMY SOUTHERN TERRITORY, SOCIAL TRUST, 1950-2000, SOURCES OF REAL INCOME IN \$1990

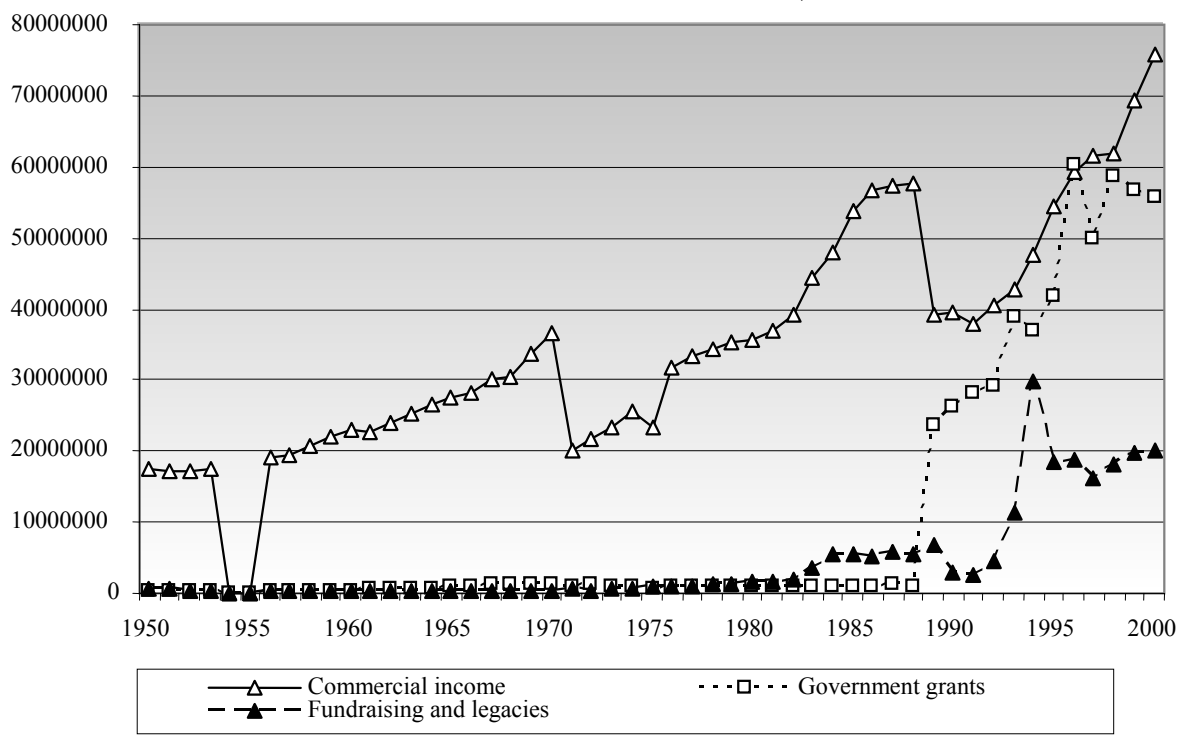

Source: Annual Financial Statements, Salvation Army Social Trust, Southern Territory.

While necessarily more aggregated than the BSL data, this chart shows the relatively larger proportion of the SA's funding that has always been derived from its commercial ventures such as opportunity shops (though this item also includes some fees and accommodation charges and some investment income). The data indicate a relatively lower reliance on government funding, though it should be noted that the financial reports show that some government per capita subsidies were, at times, included as fees and service charges. The chart illustrates the dramatic increase in income derived from fundraising, growing from the 1980s onwards. However, it should also be emphasised that-because this chart deals only with the Social Trust-some funds (including part of the Red Shield Appeal, and income from property and investments) do not appear, as they were managed in other Trusts. Note also that while data from 1950 to 2000 is provided in this chart the econometric modelling that follows uses only the period 1960-1999 for purposes of comparison with the BSL data.

The key issue in the empirical modelling adopted in this paper is to take account of the features of the data. The application of standard econometric modelling techniques 


\section{GABRIELLE BERMAN, ROBERT BROOKS \& JOHN MURPHY}

requires that the data under analysis be stationary, and relies on eliminating the possibility that time-series data over such a long span may be non-stationary. The presence of non-stationarity-primarily reflected in an upward trend in the level of the series over time-would mean that the level of the series changes following a stochastic trend. If this was so, then the use of regression analysis would be invalidated because regression is likely to find spurious results and relationships amongst the variables under analysis. For a further discussion of this issue see Kennedy (1998). Consequently, the first step required in any analysis of time-series data is to test for the stationarity of the data.

There is a range of available tests in the econometric literature to test for nonstationary data, each test having its own strengths and weaknesses. In this paper, we use the Augmented Dickey-Fuller (ADF) test. In the first instance the test is applied to the logarithms of the levels of the data for funds raised from each of the sources, considering two macroeconomic variables (GDP and unemployment (UE)). These two variables were chosen in order to capture the dimensions of the business cycle in terms of both economic activity and unemployment levels. The application of the ADF test indicated that all data are non-stationary in the levels, suggesting the presence of an upward trend in the levels of the variables. The ADF test is then applied to the differences in the log-levels data which, in effect, are the percentage changes in the data. The first differences of the variables (the percentage change in each series) are stationary.

This suggests that while the overall level of fundraising has trended upwards over time, the percentage change (the log first difference) has remained in a stable band. In other words, percentage changes in funding from year to year are relatively stable, and capable of being modelled using standard techniques. However, it is worth noting that the sample size in the analysis is only forty data-points, representing forty years of data. For a further discussion of testing issues in this context, see Kennedy (1998).

TABLE 1

SUMMARY STATISTICS FOR PERCENTAGE CHANGE IN FUNDING SOURCES

\begin{tabular}{lrccc}
\hline & Mean & Std Dev. & Skewness & Kurtosis \\
\hline BSL & 7.92 & 11.21 & -0.97 & 5.43 \\
Total & 4.68 & 17.13 & 0.77 & 4.20 \\
Fundraising & 16.16 & 35.04 & 1.79 & 9.09 \\
Govt grants & 7.70 & 126.85 & 0.16 & 8.06 \\
Com. Ventures & 8.45 & 18.89 & -0.64 & 5.47 \\
Service Fees & 11.18 & 70.81 & -0.58 & 7.66 \\
Net Investments & & & & \\
SA & 4.74 & 12.25 & -3.04 & 17.60 \\
Total & 10.08 & 34.21 & 0.11 & 4.43 \\
Fundraising & 12.30 & 50.59 & 5.14 & 30.49 \\
Govt grants & 2.82 & 13.97 & -2.81 & 13.45 \\
Com. Ventures & & & & \\
\hline
\end{tabular}


A range of summary statistics is reported in Table 1, showing the percentage change in fundraising data over the forty-year period. The Table reports the mean, standard deviation, skewness, and kurtosis for the percentage changes for each of the fundraising sources. Overall, both agencies have shown growth in their real funding over time, the BSL averaging $7.9 \%$ growth, and the SA averaging $4.7 \%$. For both agencies, the funding source that shows the highest average percentage growth is government grants at $16.2 \%$ for BSL, and $12.3 \%$ for the SA. The next highest growth sources are net investments for BSL (11.2\%) and fundraising for the SA (10.1\%). The summary statistics also indicate some variability in percentage change in funding as shown by the high standard deviation and kurtosis measures. However, the variability in the total funding is always less than that of the individual component sources, suggesting that some substitution in the funding mix is occurring over time.

Given the heterogeneity of the data, modelling the changing funding mix for the two agencies is relatively challenging. Such modelling needs to capture two key dimensions, the long-run equilibrium relationship and the short-run dynamics. For further discussion of these features, see Kennedy (1998). We model the long-run equilibrium relationship between the level of the funding source and two macroeconomic variables, GDP and UP. We then model the short-run dynamics using an error-correction model. In the error-correction model, the short run (year on year variability) in the funding source is explained by the short-run variability in other funding sources, and the short-run variability in the two macroeconomic variables. The model also includes an error-correction variable (denoted as ECT) to ensure that the short run dynamics return towards the long run equilibrium level. Further discussion on the error correction approach can be found in Kennedy (1998).

Using the two-step estimation technique of Engle and Granger (1987), the error correction model employed here is:

$\Delta \log ($ Revenue Source $)=\beta 0+\beta 1 \Delta \log (\mathrm{GDP})+\beta 2 \Delta \log (\mathrm{UE})+\beta 3 \mathrm{ECT}+\beta 4 \Delta$

Log (Other Revenue Sources) $+\varepsilon$

Here the $\beta$ 's are unknown parameters to be estimated; ECT is the error-correction term that measures the return to the long-run equilibrium from a shock in any period. The model is estimated in two forms, one excluding the other revenue sources and the other including the other revenue sources. This makes it possible to analyse whether the dynamics of a change in any given revenue source can be impacted or offset by changes in other sources of revenue. Our results are confined to the contemporaneous effects of changes, in that we do not allow for any lag structure in the analysis. This is primarily because of the restrictions associated with the small sample size.

The results are reported in Table 2 for BSL and Table 3 for SA. There are several atypical changes in revenue in the sample, which produce anomalies that need to be eliminated in order to perform a reliable regression analysis. For BSL this applies to total revenue and government grants, with the sharp reduction in government grants being due to the introduction of Job Network in 1997, while for commercial ventures the anomaly occurred somewhat earlier, in 1995 and 1996. For SA, this applied to government grants in 1989 and fundraising in 1994. It appears from the reporting in the SA financial reports that the drop in 1989 in commercial income and the corresponding 
increase in government grants is to be explained by an accounting change, to more accurately count government per capita subsidies as grants rather than commercial income.

TABLE 2

RESULTS OF ESTIMATING ERROR CORRECTION MODELS BY REVENUE SOURCE FOR BSL

\begin{tabular}{|c|c|c|c|c|c|c|c|c|c|c|c|}
\hline \multirow[b]{2}{*}{$\begin{array}{l}\Delta \log \\
\text { (GDP) }\end{array}$} & \multirow{2}{*}{$\begin{array}{l}\text { Total } \\
0.452 \\
(0.207)\end{array}$} & \multicolumn{2}{|c|}{ Net Investments } & \multicolumn{2}{|c|}{ Fundraising } & \multicolumn{2}{|c|}{$\begin{array}{c}\text { Government } \\
\text { Grants }\end{array}$} & \multicolumn{2}{|c|}{$\begin{array}{c}\text { Commercial } \\
\text { Ventures }\end{array}$} & \multicolumn{2}{|c|}{ Service Fees } \\
\hline & & $\begin{array}{l}1.220 \\
(0.673)\end{array}$ & $\begin{array}{l}2.384 \\
(0.238)\end{array}$ & $\begin{array}{l}0.068 \\
(0.918)\end{array}$ & $\begin{array}{l}-0.080 \\
(0.896)\end{array}$ & $\begin{array}{l}-1.237 \\
(0.346)\end{array}$ & $\begin{array}{l}-1.587 \\
(0.268)\end{array}$ & $\begin{array}{l}0.282 \\
(0.920)\end{array}$ & $\begin{array}{l}0.000 \\
(0.999)\end{array}$ & $\begin{array}{l}0.777 \\
(0.312)\end{array}$ & $\begin{array}{l}0.596 \\
(0.418)\end{array}$ \\
\hline $\begin{array}{l}\Delta \log \\
\text { (UE) }\end{array}$ & $\begin{array}{l}0.165 \\
(0.085)\end{array}$ & $\begin{array}{l}0.087 \\
(0.909)\end{array}$ & $\begin{array}{l}0.032 \\
(0.954)\end{array}$ & $\begin{array}{l}0.164 \\
(0.353)\end{array}$ & $\begin{array}{l}0.163 \\
(0.313)\end{array}$ & $\begin{array}{l}0.061 \\
(0.863)\end{array}$ & $\begin{array}{l}0.022 \\
(0.956)\end{array}$ & $\begin{array}{l}1.190 \\
(0.121)\end{array}$ & $\begin{array}{l}1.080 \\
(0.155)\end{array}$ & $\begin{array}{l}0.124 \\
(0.540)\end{array}$ & $\begin{array}{l}0.019 \\
(0.922)\end{array}$ \\
\hline ECT & $\begin{array}{l}0.066 \\
(0.070)\end{array}$ & $\begin{array}{l}0.267 \\
(0.044)\end{array}$ & $\begin{array}{l}0.214 \\
(0.138)\end{array}$ & $\begin{array}{l}0.230 \\
(0.036)\end{array}$ & $\begin{array}{l}0.161 \\
(0.111)\end{array}$ & $\begin{array}{l}0.152 \\
(0.112)\end{array}$ & $\begin{array}{l}0.137 \\
(0.195)\end{array}$ & $\begin{array}{l}0.567 \\
(0.000)\end{array}$ & $\begin{array}{l}0.545 \\
(0.000)\end{array}$ & $\begin{array}{l}0.080 \\
(0.170)\end{array}$ & $\begin{array}{l}0.064 \\
(0.242)\end{array}$ \\
\hline $\begin{array}{l}\Delta \log \\
\text { (Fund) }\end{array}$ & & & $\begin{array}{l}1.095 \\
(0.088)\end{array}$ & & & & $\begin{array}{l}0.043 \\
(0.916)\end{array}$ & & $\begin{array}{l}-0.930 \\
(0.247)\end{array}$ & & $\begin{array}{l}0.470 \\
(0.012)\end{array}$ \\
\hline $\begin{array}{l}\Delta \log \\
(G G)\end{array}$ & & & $\begin{array}{l}0.370 \\
(0.470)\end{array}$ & & $\begin{array}{l}0.012 \\
(0.869)\end{array}$ & & & & $\begin{array}{l}0.585 \\
(0.124)\end{array}$ & & $\begin{array}{l}-0.067 \\
(0.442)\end{array}$ \\
\hline $\begin{array}{l}\Delta \log \\
(\mathrm{CV})\end{array}$ & & & $\begin{array}{l}-0.006 \\
(0.959)\end{array}$ & & $\begin{array}{l}-0.040 \\
(0.052)\end{array}$ & & $\begin{array}{l}-0.008 \\
(0.857)\end{array}$ & & & & $\begin{array}{l}0.015 \\
(0.536)\end{array}$ \\
\hline $\begin{array}{l}\Delta \log \\
(\mathrm{SF})\end{array}$ & & & $\begin{array}{l}-1.072 \\
(0.313)\end{array}$ & & $\begin{array}{l}0.314 \\
(0.030)\end{array}$ & & $\begin{array}{l}-0.209 \\
(0.552)\end{array}$ & & $\begin{array}{l}1.668 \\
(0.040)\end{array}$ & & \\
\hline $\begin{array}{l}\Delta \log \\
\text { (NI) }\end{array}$ & & & & & $\begin{array}{l}0.064 \\
(0.093)\end{array}$ & & $\begin{array}{l}0.094 \\
(0.293)\end{array}$ & & $\begin{array}{l}-0.199 \\
(0.382)\end{array}$ & & $\begin{array}{l}-0.074 \\
(0.097)\end{array}$ \\
\hline $\begin{array}{l}\text { Adj. } \\
\text { R-Sq }\end{array}$ & 0.381 & 0.041 & 0.103 & 0.065 & 0.241 & 0.162 & -0.002 & 0.684 & 0.705 & -0.009 & 0.125 \\
\hline DW & 2.091 & 2.657 & 2.543 & 2.210 & 2.246 & 1.833 & 1.690 & 1.552 & 1.307 & 2.065 & 1.655 \\
\hline White & $\begin{array}{l}11.755 \\
(0.302) \\
\end{array}$ & $\begin{array}{l}3.917 \\
(0.688) \\
\end{array}$ & $\begin{array}{l}25.598 \\
(0.029) \\
\end{array}$ & $\begin{array}{l}2.705 \\
(0.975) \\
\end{array}$ & $\begin{array}{l}38.815 \\
(0.300) \\
\end{array}$ & $\begin{array}{l}11.978 \\
(0.286) \\
\end{array}$ & $\begin{array}{l}37.592 \\
(0.351) \\
\end{array}$ & $\begin{array}{l}17.312 \\
(0.099) \\
\end{array}$ & $\begin{array}{l}17.468 \\
(0.356) \\
\end{array}$ & $\begin{array}{l}7.541 \\
(0.580) \\
\end{array}$ & $\begin{array}{l}38.196 \\
(0.326) \\
\end{array}$ \\
\hline
\end{tabular}

Note: throughout the tables p-values are reported in parentheses.

Tables 2 and 3 report parameter estimates, and p-values in parentheses. The last three rows report the results of standard regression diagnostic tests-the adjusted R2 (R2); the Durbin-Watson test; and the White (1980) test for heteroscedasticity. The results reveal the following patterns.

First, the macroeconomic variables do not appear to influence the short-run dynamics for any of the funding sources for either of the two agencies. In general the coefficients are insignificant, being well above a level of 0.05 that would indicate significance. This suggests that there is little real relationship between the economic cycle, using GDP and unemployment levels, and changes in the agencies' reliance on different sources of funds. This is a significant finding, suggesting that an economic downturn (and the consequent rise in the needs of the poor) does not have a significant impact on government grants, fundraising capacity, or commercial income. On the other hand, the top of the economic cycle does not produce any notable benefit in increased funds. In other words, the funding for these two large welfare agencies does not appear to work either cyclically or counter-cyclically.

Second, the error-correction terms in Row 3 are not strongly significant (with the exception of commercial ventures for both agencies) and this suggests that the tendencies to return to long-run equilibrium are weak. The size and significance of the error-correction terms for commercial ventures suggest that this source of income recovers from abnormal variations much more quickly than all other sources. 
TABLE 3

RESULTS OF ESTIMATING ERROR CORRECTION MODELS BY REVENUE SOURCE FOR THE SALVATION ARMY

\begin{tabular}{llllllll}
\hline & Total & \multicolumn{2}{c}{ Fundraising } & \multicolumn{2}{c}{$\begin{array}{c}\text { Government } \\
\text { Grants }\end{array}$} & \multicolumn{2}{c}{$\begin{array}{c}\text { Commercial } \\
\text { Ventures }\end{array}$} \\
\hline $\boldsymbol{\Delta}$ log & -0.789 & -0.696 & -0.733 & -1.468 & -1.881 & -0.367 & -0.410 \\
$($ GDP) & $(0.145)$ & $(0.594)$ & $(0.586)$ & $(0.515)$ & $(0.379)$ & $(0.490)$ & $(0.429)$ \\
$\Delta \log$ (UE) & -0.236 & 0.021 & -0.003 & -0.428 & -0.644 & -0.057 & -0.115 \\
& $(0.085)$ & $(0.949)$ & $(0.994)$ & $(0.475)$ & $(0.263)$ & $(0.688)$ & $(0.417)$ \\
ECT & 0.123 & 0.122 & 0.119 & -0.062 & -0.042 & 0.316 & 0.240 \\
& $(0.170)$ & $(0.217)$ & $(0.247)$ & $(0.564)$ & $(0.685)$ & $(0.016)$ & $(0.066)$ \\
$\Delta \log$ & & & & & -0.058 & & -0.024 \\
(Fund) & & & & & $(0.796)$ & & $(0.698)$ \\
$\Delta \log$ (GG) & & & -0.003 & & & & -0.087 \\
$\Delta \log$ (CV) & & & $(0.982)$ & & & & $(0.055)$ \\
Adj. & 0.037 & 0.118 & 0.070 & 0.029 & 0.140 & 0.100 & 0.150 \\
R-Sq & & & & & & & \\
DW & 2.181 & 1.762 & 1.695 & 2.241 & 2.492 & 1.858 & 1.974 \\
White & 2.206 & 3.262 & 4.685 & 9.611 & 23.838 & 4.154 & 14.232 \\
& $(0.900)$ & $(0.860)$ & $(0.945)$ & $(0.212)$ & $(0.013)$ & $(0.656)$ & $(0.163)$ \\
\hline
\end{tabular}

Note: throughout the tables p-values are reported in parentheses.

Third, there appear to be some revealing interactions between the different revenue sources. For BSL, the pattern is as follows. Fundraising is impacted positively by service fees and net investments, in that they increase concomitantly, but fundraising is affected negatively by commercial ventures. Commercial ventures are impacted negatively by both fundraising and net investments, though neither effect is statistically significant. Higher fundraising goes with lower income from commercial ventures, and vice versa. This suggests the presence of some substitution effects to smooth out the year-to-year variations in revenue sources. But as noted above, it does not appear to be linked with the economic cycle revealed by macroeconomic measures. Interestingly, however, government grants do not appear to be part of the smoothing process. They do not significantly explain any other revenue source, nor does any other revenue source provide a significant explanation of their movements. What this suggests is that BSL has little capacity to vary government grants to help smooth out fluctuations in its other funding sources. This makes sense, because most of the organisation's government funding is tied to specific programs, and varying it is not really within the power of the agency.

For SA, no relationships are found between fundraising and the other variables. However, there is a strong relationship between commercial ventures and government grants, with a significant negative relationship. This suggests that there is some smoothing and substitution between these categories of income. But it should also be noted that accounting changes described above (such as initially counting government per capita subsidies as commercial income and later counting them as government grants) may modify this impression of a substitution effect. 


\section{GABRIELLE BERMAN, ROBERT BROOKS \& JOHN MURPHY}

Fourth, some annual dummy variables (not reported in Table 2) are needed to capture a large negative change for the BSL in total revenue and government grants in 1997 (due to Job Network changes), a large positive change for the BSL in commercial ventures in 1995 and 1996, and large positive changes for the Salvation Army in government grants in 1989 and fundraising in 1994. These dummy variables have the expected signs and are statistically significant. Finally, the regression diagnostics in the last three rows suggest an absence of heteroscedasticity and autocorrelation, which indicates that the model used is reasonably robust.

\section{Conclusions}

This paper has analysed changes in the revenue sources of the BSL and SA over time, with the aim of understanding how such agencies position themselves and ensure their stability in the context of broader economic and policy changes. The advantage of studying these two agencies is that they are both large organisations, and both report a relatively long time-series of data, though, as noted, the consistency of the SA data is more variable than for the BSL. A potential drawback of the analysis is that the results for these two organisations may not be applicable to smaller agencies or to organisations with a different mix of activities. Notwithstanding these caveats, our results suggest the presence of some substitution effects across revenue sources for the non-government welfare sector.

This suggests that these agencies have had some capacity to compensate for a drop in funding from one area by concentrating on another, but it also suggests that government policy changes that have an impact on one source of revenue need careful analysis due to their potential impacts upon other revenue sources. The analysis of the substitution relationships between these different funding sources is much clearer in the case of the Brotherhood of St Laurence. Whether deliberate or otherwise, this sort of substitution effect emerges, for example, in the inverse relationship noted between fundraising and commercial ventures.

Two conclusions of some policy significance emerge from this analysis. One is that the funding from any sources to these agencies is neither cyclical nor counter-cyclical, there being no significant relationship between macroeconomic variables and the ability of agencies to raise funds. The second is that government funding is not part of the substitution effects shown for the BSL. This is presumably because organisations have less control over government funding than they have, for example, over a decision to mount a fundraising appeal. This suggests that government funding to the nongovernment welfare sector to provide services in the mixed economy of welfare plays little or no role in helping the sector to weather the shocks and fluctuations from year to year in their other sources of revenue.

In terms of the possible relationships derived from Young's description of the supplementary, complementary, and adversarial roles of the non-profit welfare sector, our conclusions are necessarily tentative, particularly when we remember that some agencies can have all three roles at once. Supplementation might suggest that welfare agencies would increase non-government sources of funds in times of economic downturn, in order to fill a gap caused by both market and policy failure; but we find no such counter-cyclical relationship. Complementarity would suggest government funding to the agencies to perform welfare functions would increase, and this has 
clearly been the case, though it is driven more by policy decisions than by the variables analysed here. Our analysis addresses any contemporaneous complementarity effects. However, there could be further effects that work with a lag.

Finally, the adversarial role of non-profit welfare agencies would suggest the importance of maintaining independent sources of funds. Both BSL and SA have demonstrated success in this area, particularly through commercial sources and through fundraising. However, just as it is not possible from this analysis to discern whether the substitution effects noted (such as BSL's increased fundraising at a time of lower commercial income) are deliberate, nor is it easy to say that fundraising efforts have been about attaining political independence, as opposed to the desire for discretionary income.

The relationship between faith-based welfare agencies and governments is about more than funding, though funding is obviously a key point of leverage that governments have available to them and frequently employ. For the agencies, funding provides opportunities to develop programs, but it also often comes with strings of accountability, constraint, and confidentiality attached. Relationships with governments provide welfare agencies with opportunities to influence policy and contribute to public debate, but they can also limit their freedom to advocate for the poor. These dilemmas have been widely noted in the research literature and are often rephrased in terms of conflicts between the demands of the State and the Christian mission of the Churches (Howe and Oslington, 2002; Kuzma, 2000). They do not simply reduce to money, but our analysis suggests that the capacity to generate independent sources of income may be a crucial feature of a welfare agency's capacity for independent public advocacy.

\section{REFERENCES}

Alessandrini, M. (2002) "The Fourth Sector: The Impact of Neo-liberalism on Nonprofit Organisations", Paper presented to the Jubilee conference of the Australasian Political Studies Association, Australian National University, Canberra, October.

Ben-Ner, A. (2002) "The Shifting Boundaries of the Mixed Economy and the Future of the Non-profit Sector", Annals of Public and Cooperative Economics, 73, pp. 5-40.

Billis, D. and H. Glennerster (1998) "Human Services and the Voluntary Sector: Towards a Theory of Comparative Advantage", Journal of Social Policy, 27, pp. 79-98.

Bolton, B. (1980) Booth's Drum: The Salvation Army in Australia 1880-1980 (Sydney: Hodder and Stoughton).

Brotherhood of St Laurence (2001) A Brief History of the Brotherhood of St Laurence, (Fitzroy: Brotherhood of St Laurence).

Carter, I. (1967) God and Three Shillings: The Story of the Brotherhood of St Laurence (Melbourne, Lansdowne Press).

Considine, M. (2003) "Governance and Competition: The Role of Non-profit Organisations in the Delivery of Public Services", Australian Journal of Political Science, 38, pp. 63-77.

De Clifford, T. (1990) All in Good Spirit: 60 years of Life at the Brotherhood of St Laurence (Fitzroy: Brotherhood of St Laurence).

Engle, R. F. and C. W. J. Granger (1987) "Cointegration and Error Correction: Representation, Estimation and Testing”, Econometrica, 35, pp. 251-276. 


\section{GABRIELLE BERMAN, ROBERT BROOKS \& JOHN MURPHY}

Gronbjerg, K. (1991) "How Nonprofit Human Service Organizations Manage Their Funding Sources: Key Findings and Policy Implications", Nonprofit Management and Leadership, 2, pp. 159-175.

Gronbjerg, K. and L. Salamon (2003) "Devolution, Marketization, and the Changing Shape of Non-profit Relations"' in L. Salamon (ed.), The State of Non-profit America, (Washington: The Brookings Institution Press).

Gronbjerg, K. and S. Smith (1999) "Non-profit Organizations and Public Policies in the Delivery of Human Services" in Clotfelter, C. and T. Erhlich (eds), Philanthropy and the Non-profit Sector in a Changing America (Indiana: Indiana University Press).

Handfield, J. (1980) Friends and Brothers: A Life of Gerard Kennedy Tucker, Founder of the Brotherhood of St Laurence and Community Aid Abroad (Melbourne: Hyland House).

Howe, B., P. Oslington, et al. (2002) The Church and the Free Market: Dilemmas in Church Welfare Agencies Accepting Contracts from Government (Hindmarsh: South Australia, Australian Theological Forum).

Industry Commission (1995) Charitable Organisations in Australia (Melbourne: AGPS).

Kennedy, P. (1998) A Guide to Econometrics (Blackwell: Oxford, UK).

Kewley, T. H. (1973) Social Security in Australia, 1900-1972 (Sydney: University of Sydney Press).

Kuzma, A. L. (2000) "Faith-based Providers Partnering with Government: Opportunity and Temptation", Journal of Church and State, 42, pp. 38-67.

Lewis, J. (1993) "Developing the Mixed Economy of Care: Emerging issues for Voluntary Organisations”, Journal of Social Policy, 22, pp.173-192.

McDonald, C. (1997) "Government, Funded Non-profits, and Accountability", Nonprofit Management and Leadership, 8, pp. 51-64.

Moore, L. (2001) "Legitimation Issues in the State-non-profit Relationship", Non-profit and Voluntary Sector Quarterly, 30, pp. 707-719.

Rochester, C (1996) "The Impact of Funding Changes on the Voluntary Sector" in Meeting the Challenge of Change: Voluntary Action into the $21^{\text {st }}$ Century (London: NVCO Publication), pp. 24-41.

Rose-Ackerman, S. (1996) "Altruism, Nonprofits and Economic Theory", Journal of Economic Literature, 34, pp. 701-728.

Salamon, H. (1995) Partners in Public Service (Baltimore: John Hopkins University Press).

Salamon, L. and H. Anheier (1998) "Social Origins of Civil Society: Explaining the Nonprofit Sector Cross-Nationally", Voluntas: International Journal of Voluntary and Nonprofit Organizations, 9, pp. 213-248.

Salvation Army (2001) A Century of Care (Melbourne: Salvation Army).

Salvation Army (various dates) Annual Financial Statements (Social Trust, Southern Territory).

Tarling, L. (1980) Thank God for the Salvos: The Salvation Army in Australia 1880 1980 (Sydney: Harper and Row).

Tennant, M. (2001) "Governments and Voluntary Sector Welfare: Historians' Perspectives”, Social Policy Journal of New Zealand, 17, pp. 147-160. 
Victoria, Hospitals and Charities Commission (various dates) Annual Reports, (Melbourne).

Weisbrod, B. A. (1977) The Voluntary Non-profit Sector (Lexington, D.C.: Heath and Company).

White, H. (1980) "A Heteroscedasticity Consistent Covariance Matrix Estimator and a Direct test for Heteroscedasticity", Econometrica, 48, pp. 817-838.

Wilson, M. (2003) Interview by John Murphy with Mike Wilson, Brotherhood of St Laurence, 18 November.

Young, D. R. (2000) "Alternative Models of Government-Non-profit Sector Relations: Theoretical and International Perspectives", Non-profit and Voluntary Sector Quarterly, 29, pp. 149-172. 


\section{University Library}

\section{- M M N E R VA A gateway to Melbourne's research publications}

Minerva Access is the Institutional Repository of The University of Melbourne

Author/s:

Berman, G.;Brooks, R.;MURPHY, J.

Title:

Funding the non-profit welfare sector: explaining changing funding sources 1960-1999

Date:

2006-03

Citation:

Berman, G., Brooks, R. \& Murphy, J. (2006). Funding the non-profit welfare sector:

explaining changing funding sources 1960-1999. Economic Papers, 25(1), 83-99.

Publication Status:

Published

Persistent Link:

http://hdl.handle.net/11343/34096 